\title{
PENERAPAN MODEL PEMBELAJARAN SENI TARI TERPADU PADA SISWA SEKOLAH DASAR
}

\author{
Eny Kusumastuti \\ Pendidikan Sendratasik FBS Universitas Negeri Semarang \\ J1. Sekaran Gunungpati, Semarang \\ Email: enyeny68@yahoo.com
}

\begin{abstract}
The learning model is a fusion of dance integrated approach to free expression, discipline and multicultural. The problem is how to form and execution of an integrated model of learning the art of dance in elementary school students. The purpose of this study was to determine and implement an integrated model of learning in elementary school students. This study uses the approach of Research and Development $(R \mathcal{E} D)$, engineering data collection through observation, interviews, and documentation, as well as the validity of the data using triangulation of data analysis process includes three grooves activities as a system, namely data reduction, data presentation, and conclusion. The results showed that the integrated model of learning dance implemented through three stages: (1) disciplinary approaches, (2) using a multicultural approach that includes process flow that is penengenalan appreciation, understanding, appreciation and evaluation, (3) approach in which free expression using creation method which ideas and concepts, plugging into a new motion products. Advice, elementary school teachers should use the integrated arts learning model that students have the experience to appreciate and be creative. Keywords: integrated learning model, free expression, discipline, multicultural.
\end{abstract}

ABSTRAK

Model pembelajaran seni tari terpadu merupakan perpaduan pendekatan ekspresi bebas, disiplin ilmu dan multikultural. Permasalahannya adalah bagaimana bentuk dan pelaksanaan model pembelajaran seni tari terpadu pada siswa Sekolah Dasar. Tujuan penelitian ini untuk mengetahui dan menerapkan model pembelajaran terpadu pada siswa Sekolah Dasar. Penelitian ini menggunakan pendekatan Research and Development $(R \mathcal{E} D)$, teknik pengumpulan data menggunakan observasi, wawancara, dan dokumentasi, validitas data menggunakan triangulasi serta proses analisis data mencakup tiga alur kegiatan sebagai suatu sistem, yaitu reduksi data, sajian data, dan penarikan kesimpulan. Hasil penelitian menunjukkan bahwa model pembelajaran seni tari terpadu diterapkan melalui tiga tahapan yaitu (1) pendekatan disiplin ilmu, (2) pendekatan multikultural yang didalamnya menggunakan alur proses apresiasi yaitu penengenalan, pemahaman, penghayatan dan evaluasi, (3) pendekatan ekspresi bebas yang didalamnya menggunakan metode kreasi yaitu menuangkan ide dan konsep, menghubungkannya menjadi sebuah produk gerak baru.

Kata Kunci: model pembelajaran terpadu, ekspresi bebas, disiplin ilmu, multikultural.

PENDAHULUAN Seni tari dalam dunia pendidikan, khususnya pendidikan Sekolah Dasar, mempunyai dampak yang positif, bukan saja bagi upaya pelestarian seni tari, akan tetapi juga untuk kepentingan pendidikan itu sendiri. Sesuatu obyek yang sangat menarik perhatian siswa, akan sangat mempengaruhi pembentukan pola pikir siswa setelah menjadi manusia dewasa. Begitu pula penanaman nilai-nilai atau budi pekerti melalui berbagai cara (termasuk melalui seni tari), paling efektif apabila dimulai sejak dini, remaja sampai dewasa (Sujamto, 1992: 98-98). Melalui proses pendidikan, setiap individu dalam masyarakat akan mengenal, menyerap, mewarisi, dan memasukkan dalam dirinya segala unsur-unsur kebudayaannya, yaitu berupa nilai-nilai, kepercayaan, pengetahuan atau teknologi, yang diperlukan 
untuk menghadapi lingkungan. Melalui pendidikan pula, setiap individu diharapkan dapat mempelajari pranata-pranata sosial, simbol-simbol budayanya, serta dapat menjadikan nilai-nilai dari apa yang dipelajarinya itu sebagai pedoman bertingkah laku yang bermakna bagi individu yang bersangkutan dalam kehidupan sosialnya (Rohidi, 1994: 11).

Pendidikan seni bertujuan: (1) memperoleh pengalaman seni berupa pengalaman apresiasi seni dan pengalaman ekspresi seni, (2) memperoleh pengetahuan seni, misalnya teori seni, sejarah seni, kritik seni dan lain-lain (Rusyana 2000: 7). Pendidikan seni tari juga menanamkan pengaruh yang bermanfaat dari kegiatan menari kreatif terhadap pembentukan kepribadian siswa, bukan untuk menciptakan tarian-tarian untuk pertunjukan (Depdikbud, 1999: 180). Sementara itu, Kraus (1969: 271-274) mengatakan bahwa ada enam pokok tujuan tari dalam pendidikan yang bisa dikenali, yaitu: 1) sebagai pendidikan gerak, 2) meningkatkan kreativitas individu, 3) sebagai pengalaman estetis, 4) sebagai media penggabungan antar seni dan budaya serta pengalaman, 5) sebagai media sosialisasi, dan 6) media penanaman nilainilai budaya.

Tujuan yang paling utama dari pendidikan tari adalah membantu siswa melalui tari untuk menemukan hubungan antara tubuhnya dengan seluruh eksistensinya sebagai manusia. Dengan demikian pendidikan seni tari berfungsi sebagai alternatif pengembangan jiwa siswa menuju kedewasaannya. Melalui penekanan kreativitas, siswa diberi kesempatan yang seluas-luasnya di dalam proses pengungkapan gerak tarinya, sehingga hasil akhir bukanlah merupakan tujuan utama. Yang penting melalui kegiatan kreatif dan ekspresif, mereka mendapat latihan atau pengalaman untuk mengembangkan cara merasa, cara berfikir dan cara memahami serta keterampilan dalam melihat dan menyelesaikan persoalan tentang diri atau lingkungannya.

Pengalaman apresiasi dengan pengalaman ekspresi saling berhubungan dan tidak dapat dipisahkan. Begitu pula pengalaman seni dengan pengetahuan seni. Pengalaman seni merupakan dasar untuk memahami pengetahuan seni, sebaliknya, pengetahuan seni dapat menjelaskan pengalaman seni seseorang. Karena itu baik pengalaman seni, yaitu mengapresiasi seni dan berekspresi seni, maupun pengetahuan seni, merupakan tujuan pendidikan seni, yang tidak dapat diabaikan. Dengan demikian, pendidikan seni memiliki fungsi ganda, yaitu dalam pengertian pendidikan estetik (apresiasi), pendidikan seni berfungsi sebagai media pelestarian dan pewarisan nilai-nilai tradisi budaya dan dalam pengertian pendidikan kreatif, pendidikan seni berfungsi sebagai media mengembangkan kreativitas budaya (inovatif).

Peneliti ini akan mengkaji secara lebih mendalam pembelajaran seni tari di Sekolah Dasar, kemudian merumuskan atau merancang model pembelajaran seni tari melalui pendekatan terpadu pada siswa Sekolah Dasar, serta menerapkannya dalam proses pembelajaran di Sekolah Dasar. Untuk mengkaji masalah ini, dirumuskan satuan-satuan masalah dalam bentuk pertanyaan-pertanyaan sebagai berikut: (1) Bagaimanakah bentuk model pembelajaran seni tari terpadu bagi siswa Sekolah Dasar? (2) Bagaimanakah pelaksanaan model pembelajaran seni tari terpadu bagi siswa Sekolah Dasar? Tujuan penelitian ini untuk mengetahui: (1) Bagaimanakah bentuk model pembelajaran seni tari terpadu bagi siswa Sekolah Dasar (2) Bagaimanakah pelaksanaan model pembelajaran seni tari terpadu bagi siswa Sekolah Dasar.

Manfaat praktis penelitian ini adalah (1) bagi siswa, dapat mengembangkan kepekaan estetis, apresiatif, kreatif dan ekspresifnya melalui proses pembelajaran seni tari, (2) bagi guru, mendapatkan model pembelajaran seni tari melalui pendekatan terpadu guna meningkatkan proses kreativitas siswa, (3) bagi sekolah, hasil penelitian ini dapat dijadikan sebagai bahan masukan untuk proses perbaikan dan pengembangan pendidikan seni khususnya seni tari. Manfaat teoretis penelitian ini adalah penelitian ini dapat dijadikan bahan rujukan guna penelitian lebih lanjut.

\section{Pembelajaran Seni Tari sebagai Bentuk Pendidikan Seni di Sekolah Dasar}

Pembelajaran merupakan bentuk aktualisasi kurikulum resmi (official curriculum), sehingga isi pengalaman belajarnya dapat sampai kepada peserta didik sebagai sasarannya. Artinya, dalam pembelajaran harus ada perkembangan peserta didik. Demikian halnya dengan pembelajaran 
seni, yang menggunakan seni sebagai media pendidikan, diharapkan mampu mengakomodasikan kebutuhan peserta didik untuk melakukan kegiatan kreatif sesuai dengan kemampuannya masing-masing. Dengan kata lain, untuk mewujudkan tujuan pendidikan seni, harus diciptakan situasi dan kondisi yang kondusif, dan keterampilan peserta didik dengan memperhatikan tuntutan situasi dan kondisi yang relatif cepat dan selalu berubah-ubah (Ismiyanto, 1999: 374). Dalam kaitannya dengan hal tersebut, Rohidi (1993: 3) mengemukakan bahwa pendidikan kesenian, seyogyanya menjadi wahana bagi masyarakat seni yang netral dan obyektif, yang secara sadar dari waktu ke waktu berupaya mencari alternatif baru. Oleh karenanya, pendidikan kesenian hendaknya lebih ditekankan pada unsur-unsur kesenian yang berkonsep kreativitas, menampung pemikiran dan gagasan baru, serta lebih memandang ke masa depan, sehingga memungkinkan melakukan antisipasi untuk masa yang akan datang.

Pembelajaran seni tari di Sekolah Dasar, dapat menjadi salah satu upaya melestarikan seni tari. Hal ini sesuai dengan fungsi pendidikan, seperti yang dinyatakan Taba (dalam Ismiyanto, 1999) bahwa pendidikan berfungsi sebagai pemelihara dan penerus kebudayaan, alat transformasi kebudayaan, dan alat pengembang individu peserta didik. Pendidikan seni sebagai salah satu bentuk pendidikan pada hakikatnya juga: (a) mewariskan kebudayaan; (b) mengupayakan pembaharuan kebudayaan; dan (c) memenuhi kebutuhan peserta didik. Kompetensi yang diharapkan dari pembelajaran seni di Sekolah Dasar adalah: (1) mampu memadukan unsur etika, logika dan estetika, meliputi: pengetahuan, pemahaman, persepsi, analisis, evaluasi, apresiasi, dan berproduksi melalui bahasa rupa, bunyi, gerak dan peran; (2) memiliki kepekaan inderawi, perasaan estetis dan artistik melalui pengalaman bereksplorasi, berekspresi dan berkreasi secara lintas bidang dalam mendukung kecerdasan emosional, intelektual, moral, spiritual dan adversitas sesuai dengan kebutuhan dan perkembangan siswa; (3) mampu berkreasi dalam bahasa rupa, bunyi, gerak dan peran dalam mengembangkan kemampuan perseptual, pemahaman, apresiasi, kreativitas, dalam berproduksi; (4) memiliki keterampilan dasar dan mampu berkreasi berdasarkan inspirasi yang bersumber pada alam dan lingkungan sekitar siswa dalam mengolah medium seni; (5) Mampu menghargai karya sendiri dan karya orang lain serta keragaman seni budaya setempat dan nusantara; (6) Mampu mempergelarkan, menyajikan karya seni dan atau merancang, memamerkannya di kelas dan atau di lingkungan sekolah (Depdiknas, 2001: 8).

\section{Bentuk dan Pendekatan Pembelajaran Seni Tari di Sekolah Dasar}

Bentuk pembelajaran seni tari, harus disesuaikan dengan pengorganisasian materinya, yakni didasarkan pada aktivitas siswa. Selain itu juga diselaraskan dengan tujuan utama pendidikan seni, untuk peningkatan sensitivitas dan kreativitas siswa serta untuk pembaharuan masyarakat. Oleh karena itu, dalam kegiatan pembelajaran, diharapkan guru mampu menciptakan situasi dan kondisi yang kondusif bagi pengembangan individu siswa sekaligus perbaikan masyarakatnya. Sebagaimana dinyatakan oleh Dewey (dalam Ismiyanto, 1999: 378), bahwa seni dan kehidupan berada dalam hubungan yang berkesinambungan dan berkelanjutan. Kehadiran seni hanya akan dapat dipahami apabila dipandang dari makna sosial yang terkandung di dalamnya.

Bentuk pembelajaran seni di Sekolah Dasar berdasarkan pada sifat pendidikan seni itu sendiri, yaitu: multilingual, multidimensional, dan multikultural. Multilingual berarti seni bertujuan mengembangkan kemampuan mengekspresikan diri dengan berbagai cara seperti melalui bahasa rupa, bunyi, gerak dan paduannya. Multidimensional berarti seni mengembangkan kompetensi kemampuan dasar siswa yang mencakup persepsi, pengetahuan, pemahaman, analisis, evaluasi, apresiasi dan produktivitas dalam menyeimbangkan fungsi otak kanan dan kiri, dengan memadukan unsur logika, etika dan estetika, dan multikultural berarti seni bertujuan menumbuhkembangkan kesadaran dan kemampuan berapresiasi terhadap keragaman budaya lokal dan global sebagai pembentukan sikap menghargai, toleran, demokratis, beradab dan hidup rukun dalam masyarakat dan budaya yang majemuk (Depdiknas, 2001: 7). 
Pendekatan pembelajaran seni dapat dilakukan melalui pendekatan terpadu yaitu pendekatan yang dapat memberikan pemahaman secara holistik pada siswa tentang suatu konsep atau prinsip. Dalam pembelajaran seni dikembangkan kemampuan yang terpadu antara konseptual, operasional dan sintetik antar bidang seni dan lintas bidang seni. Goldberg ( 1997: 17-20) memberikan alternatif belajar tentang seni melalui pendekatan terpadu, yaitu : (1) belajar dengan seni (learning with the arts) adalah pengetahuan suatu subject matter yang dipelajari dari mata pelajaran lain dengan bantuan suatu karya seni, (2) belajar melalui seni (learning throught the arts) yaitu menggali suatu subject matter melalui berkarya seni dengan mengungkapkan suatu konsep dari mata pelajaran lain yang sedang dipelajari, dan (3) belajar tentang seni (learning with arts) yaitu memahami dan mengekspresikan serta menciptakan berbagai konsep seni kedalam karya seni, dimana siswa murni belajar seni dengan melalui proses penghayatan, penciptaan dan kreativitas.

Pembelajaran seni tari, dalam pelaksanaannya dapat menggunakan pendekatan: (1) ekspresi bebas yaitu pembelajaran seni tari dengan menggunakan ekspresi bebas, merancang kegiatan pembelajarannya dengan menggunakan model emerging curriculum yaitu kegiatan pembelajaran yang tidak dirancang sebelumnya, tetapi berkembang sesuai dengan keinginan siswa, (2) disiplin ilmu bertujuan menawarkan program pembelajaran yang sistematik dan berkelanjutan dalam empat bidang yang digeluti orang dalam dunia seni yaitu bidang penciptaan, penikmatan, pemahaman dan penilaian, dan (3) multikultural merupakan pendekatan pendidikan yang mempromosikan keragaman budaya melalui kegiatan penciptaan, penikmatan dan pembahasan keindahan rupa (visual) (Salam: 2005).

\section{Model Pembelajaran Seni Tari Terpadu di Sekolah Dasar}

Model pembelajaran yang diperlukan adalah model yang memberikan peranan pada guru untuk mengelola lingkungan alam dan fisik, sosial, budaya, dan individual, serta sekaligus hidup atau bertindak di dalamnya dengan sikapsikap yang memberi peluang berkembangnya potensi pribadi ke arah kreatif dan apresiatif terhadap seni tari. Model pendidikan tersebut dapat digambarkan sebagai sebuah sistem dengan tujuan akhir adalah kreatif dan apresiatif. Sebagai sebuah sistem, model tersebut terdiri dari unsur-unsur yang satu dengan yang lain terkait erat dalam satu kesatuan yang saling tergantung satu dengan yang lain dalam satuan sistem yang bulat dan utuh untuk mencapai suatu tujuan tertentu. Dalam hal ini unsur-unsur yang terlibat dalam model pembelajaran sebagai suatu sistem adalah (1) Guru; (2) Siswa dan potensi pribadinya; (3) Lingkungan alam dan fisik, budaya, sosial, dan individual; (4) Kreatif dan apresiatif.

Model pendidikan yang diperlukan itu dapat digambarkan dalam bentuk bagan yang dikembangkan dari Rohidi (1994: 140) berikut:

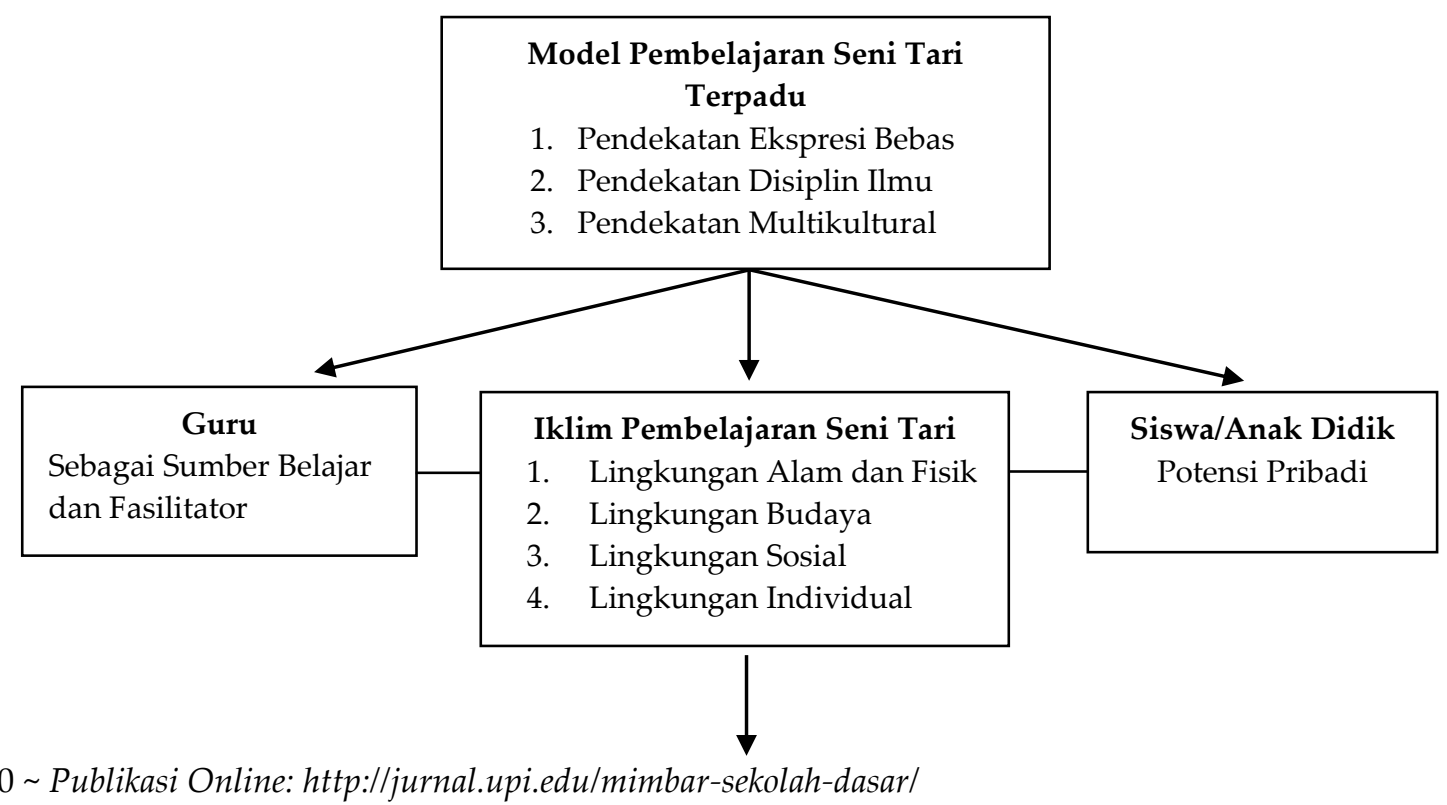


Estetis, Apresiatif, Kreatif, dan Ekspresif

Terhadap Seni Tari

1. Memiliki kepekaan estetis

2. Apresiatif terhadap karya seni tari

3. Kreatif dalam mengeksplorasi seni tari

4. Ekspresif dalam mendemonstrasikan seni tari

5. Memahami, menghargai, dan mencintai

Gambar 1. Model Pembelajaran Seni Tari di SD

\section{METODE}

Desain penelitian ini dirancang dengan menggunakan pendekatan Research and Development $(R \in \mathcal{E} D)$, yakni penelitian yang ditindaklanjuti dengan pengembangan dan diseminasi suatu model (model of) melalui siklus proses Aksi, Refleksi, Evaluasi, Replikasi, dan Inovasi. Siklus tersebut dilakukan secara sistematis dan saling terkait satu sama lain. Menurut Borg dan Gall (1983:775-776), ada 10 langkah dalam pelaksanaan R\&D yaitu (1) Research and information collecting, (2) Planing, (3) Develop prenliminary form of product, (4) Preliminary field testing, (5) Mein product revision, (6) Main field testing, (7) Operational product revision, (8) Operational field testing, (9) Final product revision, (10) Dominition and implementation.

Penelitian ini difokuskan pada proses atau kegiatan pembelajaran di Sekolah Dasar. Aspek yang menjadi perhatian adalah: materi pembelajaran, kemampuan guru, perilaku siswa, sarana dan prasarana yang tersedia, dan kondisi sumber daya lingkungan. Lokasi Penelitian di Sekolah Dasar Sekaran 1 Gunungpati.

Sumber data dalam penelitian ini terdiri dari sumber primer dan sekunder. Sumber primer, yaitu sumber data yang berupa proses pembelajaran di SD (mencakup materi, kemampuan guru, perilaku siswa dan media pembelajaran), dokumen berkaitan, dan keyinformant yang dipandang relevan dengan masalah penelitian. Sumber sekunder, yaitu sumber data lainnya yang menunjang data primer, di antaranya adalah: literatur atau dokumen yang berkaitan, nara sumber yang diharapkan mampu memberikan informasi tentang masalah yang diteliti.
Data yang diperlukan dalam penelitian ini, diperoleh dengan cara observasi, wawancara, dan dokumentasi. Observasi atau pengamatan secara langsung dan seksama terhadap obyek, untuk memperoleh data yang berkenaan dengan proses pembelajaran, sarana dan prasarana sekolah, serta sumber daya lingkungan. Pencatatan terhadap hasil amatan yang dilakukan, diikuti dengan perekaman dengan alat perekam berupa kamera foto. Wawancara mendalam (in-depth interviewing), dilakukan untuk menjaring data-data dari informan kunci, dengan struktur yang fleksibel agar informasi yang diperoleh memiliki kedalaman yang cukup. Studi dokumenter, dilakukan pada dokumen yang berkaitan dengan permasalahan penelitian, termasuk di dalamnya penelaahan terhadap sumber pustaka.

Proses analisis data mencakup tiga alur kegiatan sebagai suatu sistem, yaitu reduksi data, sajian data, dan penarikan kesimpulan. Ketiga komponen analisis tersebut aktivitasnya dilakukan dalam bentuk interaktif dengan proses pengumpulan data sebagai suatu proses siklus (Milles \& Huberman 1992). Validitas data dalam penelitian ini diupayakan dengan cara yang disebut triangulasi, sebagai cara yang paling umum digunakan dalam penelitian kualitatif.

\section{HASIL DAN PEMBAHASAN}

\section{Bentuk Model Pembelajaran Seni Tari Terpadu}

Model pembelajaran yang dikembangkan dalam proses pembelajaran seni tari ini, adalah metode yang sudah biasa digunakan oleh para guru dalam melaksanakan proses belajar mengajar seni tari dengan ceramah, tanya jawab, imam, dan drill. Metode pembelajaran yang biasa digunakan guru Sekolah Dasar untuk mengajar dikembangkan menjadi model 
pembelajaran seni tari terpadu. Model pembelajaran terpadu ini merupakan pembelajaran dengan menggunakan tiga pendekatan yaitu pendekatan ekspresi bebas, disiplin ilmu dan multikultural yang dalam penyampaiannya menggunakan metode ceramah, Tanya jawab, imam dan drill. Model pembelajaran terpadu ini diterapkan dengan memadukan pendekatan ekspresi bebas yang didalamnya menggunakan metode apresiasi dan kreasi, dengan pendekatan disiplin ilmu yang mengajarkan konsep-konsep tari serta pendekatan multikultural yaitu mengenalkan keragaman seni tari yang ada di Indonesia. Metode apresiasi dijalankan secara runtut melalui alur pengenalan, pemahaman, penghayatan dan evaluasi. Metode kreasi dijalankan melalui alur mengembangkan ide dan konsep yang diperoleh dari apresiasi, serta menuangkan ide dan konsep tersebut kedalam gerak tari sesuai dengan kaidah-kaidah tari yang berlaku serta berpijak pada keragaman seni tari yang ada di Indonesia.

Model pembelajaran yang memadukan pendekatan ekspresi bebas, disiplin ilmu dan multikultural diprogramkan melalui rencana pelaksanaan pembelajaran berdasarkan pada standar kompetensi dan kompetensi dasar yang ditarik dari Kurikulum Tingkat Satuan Pendidikan. Standar kompetensi di bidang seni tari ada dua yaitu apresiasi dan ekspresi.

Kurikulum kelas III semester 1, Standar Kompetensi mengapresiasikan karya seni tari meliputi Kompetensi dasar (1) menjelaskan simbol dalam seni tari, (2) Menunjukkan sikap apresiatif terhadap simbol yang terkandung dalam karya seni tari berdasarkan pengamatan terhadap pertunjukan. Indikator pencapaian, siswa dapat (1) menjelaskan pengertian simbol dalam seni tari, (2) menyebutkan simbol-simbol yang ada dalam seni tari. Standar Kompetensi mengeskpresikan diri melalui karya seni tari meliputi Kompetensi dasar (1) menyiapkan penyajian tarian pendek bertema tanpa iringan, (2) menyajikan tarian pendek bertema tanpa iringan. Indikator pencapaian, siswa dapat membuat tarian pendek bertema tanpa iringan.

Kurikulum kelas III semester 2, Standar Kompetensi mengapresiasi karya seni tari meliputi Kompetensi Dasar (1) menghubungkan gerak, busana, dan perlengkapan dengan simbol dalam seni tari, (2) menunjukkan sikap apresiatif terhadap simbol yang terkandung dalam karya seni tari berdasarkan pengamatan pertunjukan, (3) menunjukkan sikap apresiatif terhadap symbol yang terkandung dalam karya seni tari nusantara daerah setempat. Indikator pencapaian, siswa dapat (1) menjelaskan simbol dalam gerak tari, (2) menjelaskan simbol dalam busana tari, (3) menjelaskan simbol dalam perlengkapan tari. Standar Kompetensi mengekspresikan diri melalui karya seni tari meliputi Kompetensi Dasar (1) menyiapkan penyajian tarian pendek bertema dengan iringan, (2) menyajikan tarian pendek bertema dengan iringan, (3) mengadakan pementasan perpaduan seni tari dan musik. Indikator pencapaian, siswa dapat menyajikan tarian pendek bertema dengan iringan.

Materi pembelajaran berkait dengan pengertian tari, dikemukakan bahwa tari adalah suatu bentuk nyata ekspresi jiwa manusia yang diungkapkan dengan gerak ritmis yang indah. Unsur pokok tari adalah gerak dan unsur keindahan tari adalah wiraga, wirama dan wirasa. Wiraga merupakan gerak anggota tubuh. Wirasa merupakan perasaan yang diekspresikan melalui wajah dan gerak. Wirama merupakan keselarasan gerak dengan irama. Selain gerak, busana, rias dan properti merupakan bagian yang tidak terpisahkan dalam tari. Gerak, busana, rias dan properti dalam tari masingmasing mempunyai simbol. Simbol-simbol tersebut mempunyai makna. Semua materi pembelajaran tersebut diberikan dengan menggunakan metode ceramah dan tanya jawab saja. Hasilnya siswa lebih sering menanggapi dengan cara menyepelekan. Terlebih lagi bila sudah sampai pada materi praktek, guru lebih sering menggunakan metode meniru atau sering disebut imam.

Model pembelajaran seni tari terpadu ini dilakukan dengan berurutan secara terpadu dengan menggunakan pendekatan ekspresi bebas, disiplin ilmu dan multikultural. Setiap pokok bahasan bisa dijelaskan dengan menggunakan ketiga pendekatan secara berurutan atau bersamaan.

Langkah pertama dalam model pembelajaran seni tari terpadu yaitu penggunaan pendekatan disiplin ilmu. Standar Kompetensi dan Kompetensi Dasar kelas III Sekolah Dasar adalah 
apresiasi dan ekspresi tari Nusantara dilihat dari simbol dan pemaknaannya. Guru menjelaskan pengertian tari dan elemen-elemen tari secara konseptual kepada siswa dengan menggunakan pendekatan disiplin ilmu. Dalam pembelajaran kontekstual ini, guru menjelaskan apakah pengertian tari, unsur-unsur tari yang meliputi gerak, iringan, busana, rias, properti dan pentas. Selain itu, guru juga menjelaskan pengertian simbol dan pemaknaannya secara sederhana.

Setelah siswa memahami konsep-konsep tari dan unsur-unsurnya, guru mengajak siswa untuk melakukan proses apresiasi dengan cara melihat karya seni tari Nusantara. Di dalam sesi ini, guru menggunakan pendekatan multikultural dimana siswa diajak untuk mengenal berbagai ragam seni budaya Nusantara. Proses apresiasi ini melalui beberapa langkah yaitu pengenalan, pemahaman, penghayatan dan evaluasi.

Pada tahap pengenalan, siswa terlebih dahulu diperkenalkan kontekstual tari yang disajikan kepada siswa meliputi jenis tarian, asal tarian, sejarah tarian,fungsi, simbol dan maknanya. Setelah apresiasi awal selesai dijelaskan dari sisi kontekstualnya, langkah selanjutnya adalah mempertontonkan kepada siswa wujud tariannya. Tarian yang disajikan kepada siswa adalah tarian yang sudah jadi dengan menggunakan media audio visual. Kelebihan penggunaan video visual ini dapat menampilkan secara utuh sebuah pertunjukan secara lengkap dari awal sampai akhir bahkan dapat di putar berulang-ulang. Hal ini sangat membantu guru dalam menjelaskan tarian yang dipertontonkan kepada siswa. Proses mempertontonkan bentuk tarian jadi ini disebut mempertontonkan wujud tari dari sudut tekstualnya. Siswa diminta untuk betul-betul mengamati tarian berdasarkan gerak, ritme, keindahan, busana, rias, dan propertinya.

Proses pengenalan tersebut diatas, diikuti dengan proses pemahaman. Siswa melakukan proses pemahaman tentang gerak, dan unsurunsur dalam tari tersebut. Semua sisi teks dan konteks juga dijelaskan dalam sesi ini. Metode yang digunakan untuk menjelaskan teks dan konteks menggunakan metode ceramah dan Tanya jawab. Metode ceramah dan Tanya jawab digunakan karena dalam proses pemahaman berkaitan dengan logika atau kognitifnya saja bukan aspek afektifnya.
Tahap pemahaman usai, disusul dengan tahap penghayatan. Siswa tidak akan kesulitan untuk menghayati teks dan konteks materi tari yang dipertontonkan karena terlebih dahulu sudah memahaminya.

Tahap berikutnya adalah evaluasi atau penilaian, yang menjadi pusat perhatian guru dalam proses pembelajaran. Penilaian dalam seni tidak berkaitan dengan benar dan salah, tetapi subyektif berkaitan dengan indah atau tidak indah, menarik atau tidak menarik, bagus atau tidak bagus dan lain sebagainya. Apabila siswa menilai karya tari yang dilihatnya banyak mengandung unsur positifnya, maka karya seni tari tersebut akan mendapatkan penghargaan selayaknya dari siswa.

Proses pembelajaran berikutnya adalah menyiapkan sajian tarian pendek bertema dengan menggunakan pendekatan ekspresi bebas. Kreasi atau ekspresi ini berangkat dari proses apresiasi. Dari proses apresiasi, siswa diharapkan mampu memiliki atau menumbuhkan ide dan konsep untuk mengekspresikan kembali atau mengkreasikan kembali materi tarian baru. Setiap siswa diharapkan mampu mempunyai ide dan konsep yang berbeda-beda. Ide ini tidak hanya bisa didapatkan dari hasil melihat sajian tarian yang dipertontonkan guru kepada siswanya, akan tetapi bias diperoleh dari fenomena alam dan sekitarnya, misalnya gerak pohon tertiup angin, aktivitas orang-orang yang ada disekitarnya misalnya nelayan, petani, pedagang, aktivitas binatang, daun yang berjatuhan, ombak lautan dan masih banyak lagi yang lainnya.

Ide siswa yang berbeda-beda akan memunculkan konsep yang berbeda pula. Pendekatan ekspresi bebas ini memberikan ruang dan waktu bagi siswa untuk bebas berekspresi dan berkreasi. Siswa bebas menuangkan ide dan konsepnya dalam bentuk garapan gerak tari yang sederhana. Peran guru di sini, sebagai fasilitator saja. Apabila ada ide dan konsep yang sama diantara siswa, pasti penuangan ide dan konsepnya berbeda. Setelah siswa memiliki ide dan konsep, guru meminta siswa menuangkannya ke dalam bentuk gerak tari. Siswa menghubung-hubungkan apa yang ada di benak berkait dengan ide dan konsep akan menumbuhkan jalinan ide, konsep dan menghubung-hubungkannya untuk 
mendapatkan sesuatu yang baru. Berangkat dari menghubung-hubungkan apa yang ada di benak berkait dengan ide dan konsep dari hasil proses apresiasi, akan menumbuhkan jalinan ide, konsep dan akhirnya akan menghasilkan sesuatu yang baru. Dalam proses ini, siswa sudah bisa dikatakan melalui proses penciptaan karya seni tari.

Proses siswa dalam merangkaikan gerak, guru tidak boleh ikut campur didalamnya. Guru hanya berperan sebagai fasilitator saja, cukup memantau dan mengarahkan serta memberi masukan, manakala melihat ada gerak yang tidak sesuai dan sudah sesuai. Setelah rangkaian gerak sudah jadi, guru mengajarkan siswa untuk membuat iringan.

Berdasarkan proses pembelajaran seperti yang telah diuraikan di atas, dapat digambarkan bagan model pembelajaran seni tari terpadu berikut ini.

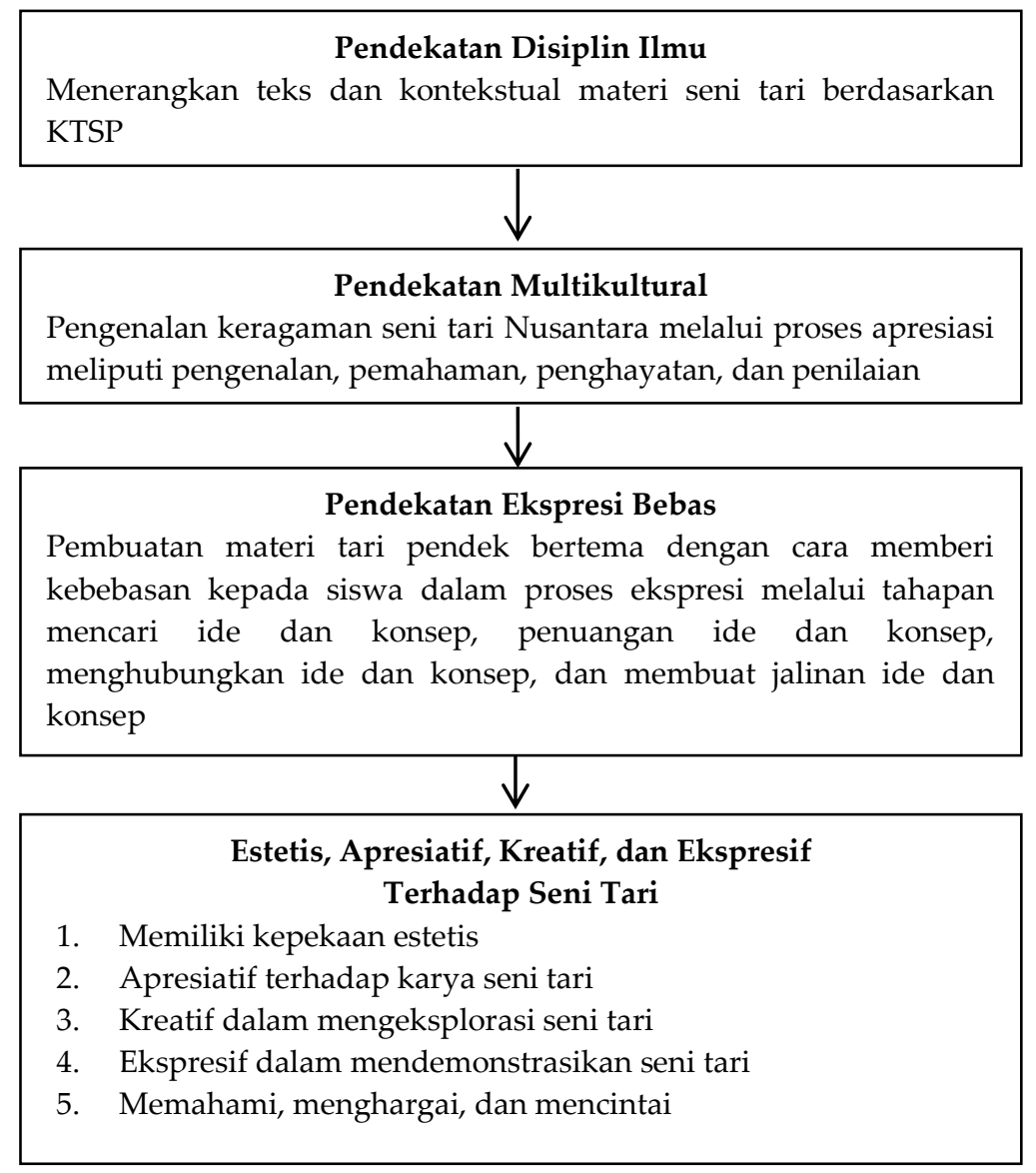

Gambar 2. Model Pembelajaran Seni Tari Terpadu

Proses Pelaksanaan Model Pembelajaran Seni Tari Terpadu

Model pembelajaran seni tari terpadu untuk Sekolah Dasar telah diterapkan dilapangan yaitu di Sekolah Dasar Negeri Sekaran 1 Gunungpati Semarang. Penerapan model ini melibatkan guru seni budaya bidang seni tari dan siswa kelas 3 . Langkah awal yang peneliti lakukan yaitu mengadakan pertemuan dengan guru seni budaya untuk menjelaskan tentang model pembelajaran seni tari terpadu untuk Sekolah Dasar sesuai dengan isi Kurikulum Tingkat Satuan Pendidikan. Hal ini dilakukan karena berdasarkan pengamatan awal, pembelajaran seni budaya khususnya seni tari masih memberikan materi kepada siswanya dengan tujuan agar siswa terampil menari bukan siswa berpengalaman menari. Setelah guru memahami model pembelajaran seni tari terpadu yang disampaikan peneliti, peneliti meminta guru tersebut untuk mencoba memberikan pelajaran seni tari dengan menggunakan model pembelajaran seni tari terpadu sesuai saran dan bimbingan peneliti.

Proses penerapan model pembelajaran seni tari terpadu di Sekolah Dasar dapat dijabarkan dalam tiga siklus sebagai berikut: 


\section{Siklus Pertama}

Pada tahap pertama ini, peneliti mengarahkan guru untuk dapat menyampaikan penjelasan mengenai tujuan pembelajaran seni tari kepada siswanya. Pada pertemuan ini, guru tidak menyuruh siswanya untuk langsung menari, tetapi guru lebih memberikan motivasi kepada siswa untuk belajar memahami ruang lingkup tari dan unsur-unsurnya. Proses ini menggunakan pendekatan disiplin ilmu. Dengan pemberian motivasi dari guru, terlihat para siswa baik putra dan putri merasa senang, menghargai dan juga memberikan respon positif dalam mengikuti pembelajaran seni tari.

\section{Siklus Kedua}

Pada siklus kedua, peneliti memberikan media audio visual untuk proses pembelajaran apresiasi tari kepada guru. Media audio visual ini digunakan untuk memperjelas materi yang akan disampaikan oleh guru kepada siswanya. Pada tahap kedua ini, pendekatan yang digunakan adalah multikultural yaitu mengenalkan ragam seni tari Nusantara melalui proses apresiasi yaitu melihat salah satu contoh tari bentuk Nusantara melalui media audio visual. Guru mencoba menerapkan model ini kepada siswa dengan menayangkan contoh tari bentuk Nusantara dari media audio visual. Sebelumnya, guru sudah menjelaskan tujuan pembelajaran seni tari kepada siswanya, selanjutnya guru menjelaskan materi tari bentuk yang ditayangkan tersebut. Guru menjelaskan segala sesuatu yang berkait dengan materi yang ditampilkan dalam video audio visual tersebut, mulai dari gerak, busana, rias, properti, iringan, simbol-simbol dan maknanya. Tanggapan siswa dalam tahapan proses pembelajaran ini, sangat antusias. Siswa bisa melihat langsung apa saja yang diterangkan guru secara jelas, tidak hanya sekedar membayangkan saja. Bahkan pada saat guru menyuruh siswa untuk bersama-sama menirukan ragam gerak tari bentuk yang ditayangkan tersebut, siswa mau memeragakannya.

\section{Siklus Ketiga}

Pada siklus ketiga ini, peneliti meminta guru untuk menerapkan pendekatan pembelajaran seni tari ekspresi bebas pada anak. Berdasarkan materi tari bentuk yang sudah disampaikan melalui media audio visual pada siklus kedua, guru mengajak siswa untuk mengekspresikan kembali apa yang sudah dilihatnya ke dalam ragam bentuk gerak tari menurut ide dan konsep masing-masing siswa. Selain media audio visual yang sudah dilihat oleh siswa, guru juga memberikan gambaran lain dalam bentuk cerita kepada siswa, misalnya dengan menggambarkan gerak tumbuhan yang sedang tertiup angin, manusia dengan beragam profesinya, gerak binatang dan masih banyak yang lainnya. Dengan arahan dan bimbingan guru, siswa diminta untuk menuangkan ide dan konsep hasil dari pengamatannya ke dalam gerak tari. Siswa dengan antusias melakukannya, hal ini terlihat dari ekspresi gembira para siswa. Setelah siswa mampu menuangkan ide dan konsep serta menghubungkannya ke dalam rangkaian gerak tari, siswa diberi kesempatan untuk menampilkannya di hadapan siswa lain. Sementara siswa lain memperhatikan dengan sungguh-sungguh serta memberikan tepuk tangan yang meriah sebagai bentuk apresiasi kepada temannya yang maju.

\section{SIMPULAN}

Model pembelajaran seni tari terpadu ini dilakukan dengan berurutan secara terpadu dengan menggunakan pendekatan ekspresi bebas, disiplin ilmu dan multikultural. Setiap pokok bahasan bisa dijelaskan dengan menggunakan ketiga pendekatan secara berurutan atau bersamaan. Pertama dimulai dari pendekatan disiplin ilmu meliputi menerangkan teks dan kontekstual materi seni tari berdasarkan KTSP, kedua, pendekatan multikultural meliputi pengenalan keragaman seni tari Nusantara melalui proses apresiasi meliputi pengenalan, pemahaman, penghayatan, dan penilaian, ketiga, pendekatan ekspresi bebas meliputi pembuatan materi tari pendek bertema dengan cara memberi kebebasan kepada siswa dalam proses ekspresi melalui tahapan mencari ide dan konsep, penuangan ide dan konsep, menghubungkan ide dan konsep, dan membuat jalinan ide dan konsep.

Pelaksanaan model pembelajaran seni tari terpadu melalui beberapa tahapan dengan menggunakan istilah siklus, siklus pertama, guru menyampaikan materi pelajaran dengan menggunakan pendekatan disiplin ilmu, siklus 
kedua, guru memberikan proses apresiasi dengan cara menayangkan video kepada siswa, dengan menggunakan pendekatan multikultural, siklus ketiga menggunakan pendekatan ekspresi bebas, siswa diminta mengekspresikan kembali video yang sudah dilihat siswa berdasarkan ide dan konsep masing-masing siswa.

\section{REFERENSI}

Depdikbud. (1999). Konsep Pendidikan Kesenian, Panduan Teknis Sebagai Pelengkap Penataran Pendidikan Kesenian Bagi Guru Taman Kanakkanak dan Guru SD di DKI Jakarta. Jakarta: Depdikbud.

Depdiknas. (2001). Kurikulum Berbasis Kompetensi, Mata Pelajaran Seni dan Budaya Sekolah Dasar. Jakarta: Depdiknas.

Golberg, Merryl. (1997). Arts and Learning. An Integrated Approach to Teaching and Learning in Multicultural and Multilingual settings. New York: Longman.

Ismiyanto, Pc. S. Petrus. (1999). "Creative Problem Solving dalam Pembelajaran Pendidikan Seni Rupa: Sebuah Penawaran Pendekatan Pembelajaran" dalam Lingua Artistika No. 3 Th XXII Sepetember 1999, Semarang: IKIP Semarang Press.

Kraus, Richard. (1969). History of The Dance In Art And Education. New Jersey: Prentice Hall inc. Englewod Cliffs.
Miles, Matthew B. dan A. Michael Huberman. (2007). Qualitative Data Analysis. Terjemahan Tjetjep Rohendi Rohidi. Jakarta: UI Press.

Rohidi, T.R., (1993). "Pendidikan Seni Rupa Sebagai Pengembangan Potensi dan Pelestarian Nilai-nilai Estetik", Makalah, Semarang, 26 September 1992.

--------------- (1994). "Pendekatan Sistem Budaya dalam Penelitian Seni dan Pendidikan Seni (Sapuan Kuas Besar dalam Kerangka Ilmu Sosial), makalah Seminar Nasional Pendekatan-pendekatan dalam Penelitian Seni dan Pendidikan Seni, dalam rangka Dies Natalis XXIX IKIP Semarang, Semarang, Tanggal 11 April 1994.

(1994). Pendekatan Sistem Sosial Budaya dalam Pendidikan, IKIP Semarang Prees, Semarang.

Rusyana, Yus. (2000). Tujuan Pendidikan Seni. Gelar: Jurnal Ilmu dan Seni STSI Surakarta: STSI Press.

Salam, Sofyan. (2005). Paradigma Dan Masalah Pendidikan Seni. Semarang: PPS UNNES.

Sujamto. 1992. Wayang dan Budaya Jawa, Semarang: Dahara Prize. 